\title{
ANTIBIOTIC PROPHYLAXIS IN TRANSURETHRAL RESECTIONS: WHAT ARE THE CRITERIA THAT SHOULD BE FOLLOWED?
}

\author{
CĂTĂLIN PRICOP ${ }^{1,2 \#}$, LIGIA FLORENTINA FURTUNESCU ${ }^{3 \#}$, DANIEL RĂDĂVOI ${ }^{3,4 *}$, \\ VIOREL JINGA $^{3,4}$, ALIN CUMPĂNAȘ ${ }^{5}$, DANA-TEODORA ANTON-PĂDURARU ${ }^{6}$, ADELINA \\ MIRON $^{2}$, CRISTIAN TOMA ${ }^{3}$, DRAGOȘ PUIA ${ }^{1,2}$ \\ 1 “Grigore T. Popa” University of Medicine and Pharmacy, Faculty of Medicine, Discipline of Urology, 16 Universităţii \\ Street, 700115, Iaşi, Romania \\ 2 "Dr. C. I. Parhon” Clinical Hospital, Clinic of Urology, 50 Carol I Boulevard, 700503, Iaşi, Romania \\ 3 "Carol Davila" University of Medicine and Pharmacy, Faculty of Medicine, 37 Dionisie Lupu Street, Bucharest, Romania \\ 4 "Prof. Dr. Theodor Burghele" Clinical Hospital, Department of Urology, 20 Panduri Road, Bucharest, Romania \\ ${ }^{5}$ University of Medicine and Pharmacy, Faculty of Medicine, Discipline of Urology, Timișoara, Romania \\ 6 "Grigore T. Popa" University of Medicine and Pharmacy, Faculty of Medicine, Department of Mother and Child Medicine, \\ 16 Universităţii Street, Iaşi, Romania
}

*corresponding author: radadaniel@yahoo.com

${ }^{\#}$ Authors with equal contribution.

Manuscript received: January 2020

\begin{abstract}
Antibiotic prophylaxis for urinary tract infections (UTIs) after endourology procedures is a controversial subject. Our objectives are the evaluation of postoperative incidence of bacteriuria and infectious complications after endoscopic surgery, to create a profile for who needs prolonged antibiotic therapy, and to analyse the risk factors that lead to the appearance of postoperative UTIs. We carried out a non-randomized, prospective study. Patients who underwent transurethral resection of bladder tumour (TUR-BT) or transurethral resection of prostate (TUR-P) and had a negative preoperative urine culture were included. Out of 705 subjects TUR-P $13.4 \%$, respectively TUR-BT $7.2 \%$ had positive cultures. The encountered bacteria were E. coli, Klebsiella, Enterococcus, and others with MAR index ranging from 0.18 to 0.75 (Pseudomonas). The study suggests that prolonging antibiotics at home is not useful in patients who have undergone TUR-P, but it might decrease the risk of TUR-BT patients. Keeping the urinary catheter for a prolonged time increases the risk of UTIs.
\end{abstract}

\section{Rezumat}

Profilaxia antibiotică pentru infecțiile urinare (ITU) după proceduri endoscopice rămâne un subiect controversat. Obiectivele noastre au fost evaluarea incidenței postoperatorii ale bacteriuriei și complicațiilor infecțioase dupa intervenții endoscopice, de a crea un profil pentru pacientul care necesită antibioterapie prelungită şi pentru a analiza factorii de risc care conduc la apariția infecțiilor urinare. Am desfăşurat un studiu nerandomizat, prospectiv. Pacienții care au beneficiat de rezecția transuretrală a vezicii urinare (TUR-V) și rezecția transuretrală a prostatei (TUR-P) cu uroculturi negative preoperatorii au fost introduși în studiu. Din 705 pacienți 13,4\% TUR-P, respectiv 7,2\% TUR-V au avut culturi pozitive. Bacteriile întâlnite au fost E. coli, Klebsiella, Enterococus şi altele cu un index MAR între 0,18 și 0,75 (Pseudomonas). Studiul sugerează că prelungirea antibioterapiei la domiciliu nu este utilă pentru pacienții TUR-P, dar poate reduce riscul ITU pentru pacienții TUR-V. Menținerea cateterului un timp prelungit crește riscul de ITU.

Keywords: antibiotic, prophylaxis, urinary tract infection

\section{Introduction}

The main goal of endourology is to minimise surgical aggression by using natural access ways. Urinary tract infections (UTIs) remain one of the possible complications that we must take into account [1]. There are multiple sources of UTIs in the endourology of the lower urinary tract: prostatic tissue [2], bacterial colonisation of a bladder tumour, and alteration of the bladder endothelium [3] or through the urinary catheter [4]. Antibiotic prophylaxis for the prevention of UTIs and sepsis after endoscopic urologic procedures is still a controversial subject. Data from specialty literature has suggested that surgical instrumentation is associated with a higher incidence of UTIs and possible septicaemia [2]. The incidence of UTIs after TUR-P (transurethral resection of the prostate) has varied from $6 \%$ to $60 \%$ in different studies, and when it comes to TUR-BT (transurethral resection of the bladder tumour), it has varied from $3 \%$ to $38.9 \%[5,6,7]$. A longer duration of the intervention, disconnecting the closed urine drainage system, and a prolonged postoperative urinary catheterisation of over 3 days are risk factors associated with postoperative bacteriuria. Living in a society where efficiency and quality management of resources are of high relevance, every 

to the overall economy of healthcare. The management of contemporary organizations can no longer be conceived without efficient and rational use of resources [8]. Hence, choosing the proper antibiotic therapy in every particular procedure brings an advantage to the overall health-care economy.

The objectives of this study are the evaluation of the postoperative incidence of bacteriuria and infectious complications after TUR-BT and TUR-P, to create a profile for the patient who needs a prolonged antibiotic administration in this context, and to analyse the risk factors that lead to the appearance of postoperative infectious complications.

\section{Materials and Methods}

\section{Materials}

We carried out a non-randomised, prospective study in the Urology Department of the "Dr. C. I. Parhon" Hospital in Iași, Romania, and the Urology Department of the "Prof. Dr. Th. Burghele" Clinical Hospital in Bucharest, Romania, from January 2018 to August 2019. We included in the study patients who underwent TUR-BT or TUR-P and had a negative preoperative urine culture.

The inclusion criteria were: patients with a negative urine culture, without recent antibiotic therapy or preoperative urinary catheter. The exclusion criteria were: patients with a urinary catheter, the absence of a preoperative urine culture, and patients who have undergone preoperative empiric antibiotic therapy at home for other reasons.

Based on the antibiotic prophylaxis regimen that was chosen by the attending physician, we split up the patients into 3 groups. The first group (Group A) was made up of patients who only received one dose of antibiotics preoperatively, while Group B comprised of patients who received antibiotics preoperatively and therapeutical strategy and its consequences contribute

postoperatively during the time they had a urinary catheter in place, and Group C was made up of patients who received antibiotic therapy during their hospital stay and at home after discharge. All patients were asked for a control urine culture after 14 - 21 days postoperatively (at least 1 week from the last antibiotic dose). All significant data regarding the patients (age, sex, provenience: rural-R, urban-U, history of UTIs, associated pathologies) and intraoperative aspects (prostate volume, bladder postvoid residue for the patients who underwent TUR-P, and data about the bladder tumour single/multiple, infiltrative, necrotic) for the patients who underwent TUR-BT were collected. We also registered the period in which urinary catheter was left in place and intraoperative and postoperative complications. All patients gave their informed written consent and the research was compatible with the Declaration of Helsinki.

Statistical analysis. The Chi-squared with Yates correction, ANOVA, and Fisher tests were used for the statistical analysis. Multiple antibiotic resistance (MAR) index was determined by using the formula described by Krumperman MAR = a/b, where " $a$ " represents the number of antibiotics to which the test isolate depicted resistance and "b" represents the total number of antibiotics to which the test isolate has been evaluated for susceptibility [9].

\section{Results and Discussion}

A total of 705 patients were included in the study: Group A comprised 115 patients (16.3\%), Group B 417 patients (59.14\%), and Group C 173 patients (24.55\%). The characteristics of all patients who were included in the study are shown in Table I.

The characteristics of patients who underwent TUR-P and TUR-BT split into groups according to their control of urine cultures (positive or negative), are shown in Tables II and III, respectively.

Table I

Characteristics of patients included in the study

\begin{tabular}{|l|c|c|c|c|c|c|c|}
\hline & \multicolumn{2}{|c|}{ Group A } & \multicolumn{2}{c|}{ Group B } & \multicolumn{2}{c|}{ Group C } & p \\
\hline Control urine culture & Neg & Pos & Neg & Pos & Neg & Pos & \\
\hline No. of patients & 100 & 15 & 379 & 38 & 159 & 14 & $>0.05$ \\
\hline Mean Age & 63.48 & 61.55 & 68 & 72,35 & 66,72 & 63.59 & $>0.05$ \\
\hline Gender F/M & $7 / 93$ & $12 / 3$ & $63 / 316$ & $4 / 34$ & $27 / 132$ & $0 / 14$ & $>0.05$ \\
\hline Provenience Rural/Urban & $14 / 86$ & $5 / 10$ & $177 / 202$ & $16 / 22$ & $38 / 121$ & $10 / 4$ & $<\mathbf{0 . 0 5}$ \\
\hline Mean hospitalization period (days) & 4.81 & 3.28 & 5.6 & 5.89 & 5.39 & 4.69 & $<\mathbf{0 . 0 5}$ \\
\hline History of UTI & $24(3.4 \%)$ & $2(0.28 \%)$ & $47(6.66 \%)$ & $15(2.12 \%)$ & $18(2.55 \%)$ & $16(2.26 \%)$ & $>0.05$ \\
\hline Chronic Kidney Disease & $32(4.53 \%)$ & $7(0.99 \%)$ & $67(9.5 \%)$ & $4(0.56 \%)$ & $18(2.55 \%)$ & $1(0.14 \%)$ & $<\mathbf{0 . 0 5}$ \\
\hline Diabetes & $10(1.41 \%)$ & $2(0.28 \%)$ & $34(4.82 \%)$ & $4(0.56 \%)$ & $16(2.26 \%)$ & $2(0.28 \%)$ & $>0.05$ \\
\hline Associated Cancer & $3(0.42 \%)$ & $2(0.28 \%)$ & $21(2.97 \%)$ & $4(0.56 \%)$ & $5(0.7 \%)$ & $2(0.28 \%)$ & $>0.05$ \\
\hline Chronic Hepatitis & $5(1.44 \%)$ & $1(0.28 \%)$ & $5(1.44 \%)$ & 0 & $7(2.02 \%)$ & 0 & $<\mathbf{0 . 0 5}$ \\
\hline Preoperative Mean White Blood Cells & 8524 & 7378 & 7272 & 7375 & 7307 & 7876 & $>0.05$ \\
\hline Preoperative Mean Haemoglobin (g/dL) & 13.85 & 11.37 & 13.9 & 12.97 & 13.51 & 13.42 & $>0.05$ \\
\hline Leukocyturia & $69(9.78 \%)$ & $8(1.13 \%)$ & $137(19.43 \%)$ & $32(4.53 \%)$ & $87(12.34 \%)$ & $3(0.42 \%)$ & $<\mathbf{0 . 0 5}$ \\
\hline Multiple tumours & $25(3.54 \%)$ & $3(0.42 \%)$ & $104(14.75 \%)$ & $15(2.12 \%)$ & $52(7.37 \%)$ & $1(0.14 \%)$ & $>0.05$ \\
\hline Deep Resection & $36(5.10 \%)$ & $2(0.28 \%)$ & $85(12.05 \%)$ & $32(4.53 \%)$ & $40(5.67 \%)$ & $2(0.28 \%)$ & $>0.05$ \\
\hline Mean days with urinary catheter & 2.32 & 2.91 & 2.43 & 32.19 & 3.2 & 3.08 & $<\mathbf{0 . 0 5}$ \\
\hline
\end{tabular}


Patients who underwent TUR-P

\begin{tabular}{|l|c|c|c|}
\hline \multicolumn{1}{|c|}{ Control urine culture } & Negative & Positive & p \\
\hline No. patients & 142 & 22 & \\
\hline Mean age & 70,44 & 66,9 & $>0.05$ \\
\hline Provenience R/U & $60 / 82$ & $13 / 9$ & $>0.05$ \\
\hline Mean hospitalization time (days) & 5.8 & 6,3 & $>0.05$ \\
\hline History of UTI & $20(14.08 \%)$ & $11(50 \%)$ & $<\mathbf{0 . 0 5}$ \\
\hline Chronic Kidney Disease & $8(5.63 \%)$ & $1(4.54 \%)$ & $>0.05$ \\
\hline Diabetes & $27(19.01 \%)$ & $7(31.8 \%)$ & $>0.05$ \\
\hline Associated neoplasia & $8(5.63 \%)$ & $1(4.54 \%)$ & $>0.05$ \\
\hline Chronic hepatitis & $1(0.7 \%)$ & 0 & $>0.05$ \\
\hline Preoperative Mean White Blood Cells & 7476 & 7878 & $>0.05$ \\
\hline Preoperative Haemoglobin(g/dL) & 14.11 & 14,21 & $>0.05$ \\
\hline Preoperative leukocyturia & $77(54.22 \%)$ & $7(31.8 \%)$ & $>0.05$ \\
\hline Days with a urinary catheter & 2.41 & 3.27 & $<\mathbf{0 . 0 5}$ \\
\hline Post-Voiding Residue $<100 \mathrm{~mL}$ & $88(61.9 \%)$ & $15(68.18 \%)$ & $<\mathbf{0 . 0 5}$ \\
\hline Post-Voiding Residue $>100 \mathrm{~mL}$ & $54(38.02 \%)$ & $10(45.45 \%)$ & $<\mathbf{0 . 0 5}$ \\
\hline Associated bladder stones & $32(22.53 \%)$ & $3(13.16 \%)$ & $>0.05$ \\
\hline Prostate neoplasia & $17(11.97 \%)$ & $3(13.16 \%)$ & $>0.05$ \\
\hline
\end{tabular}

Table III

Patients who underwent TUR-BT

\begin{tabular}{|l|c|c|c|}
\hline \multicolumn{1}{|c|}{ Control urine culture } & Negative & Positive & p \\
\hline No. of patients & $502(92.79 \%)$ & $39(7.20 \%)$ & \\
\hline Mean age & 66,78 & 69,47 & $>0.05$ \\
\hline Provenience R/U & $213 / 289$ & $16 / 23$ & $>0.05$ \\
\hline Gender F/M & $120 / 382$ & $10 / 29$ & $>0.05$ \\
\hline Days of hospitalization & 5.30 & 5.35 & $>0.05$ \\
\hline History of UTI & $87(17.3 \%)$ & $11(28.2 \%)$ & $>0.05$ \\
\hline Chronic Kidney Disease & $99(19.72 \%)$ & $3(7.69 \%)$ & $>0.05$ \\
\hline Diabetes & $34(6.77 \%)$ & $3(7.69 \%)$ & $>0.05$ \\
\hline Associated neoplasia & $17(3.38 \%)$ & $7(17.94 \%)$ & 0.005 \\
\hline Chronic hepatitis & $19(3.78 \%)$ & $2(5.12 \%)$ & $>0.05$ \\
\hline Preoperative Mean White Blood Cells & 7395 & 7443 & $>0.05$ \\
\hline Preoperative Haemoglobin (g/dL) & 13.85 & 13.46 & $>0.05$ \\
\hline Preoperative leukocyturia & $231(46.01 \%)$ & $22(56.41 \%)$ & $>0.05$ \\
\hline Days with a urinary catheter & 2.50 & 3.04 & $<\mathbf{0 . 0 5}$ \\
\hline Tumour necrosis & $3(0.59 \%)$ & - & - \\
\hline Multiple tumours & $206(41.03 \%)$ & $15(38.46 \%)$ & $<\mathbf{0 . 0 5}$ \\
\hline Deep resection & $130(25.89 \%)$ & $24(61.53 \%)$ & $>0.05$ \\
\hline
\end{tabular}

The general rate of positive urine cultures was $13.4 \%$ (22 cases out of 164) for TUR-P and 7.2\% (39 cases out of 541) for TUR-BT. It is common to encounter single episodes of acute urinary retention that require 1-2 intermittent catheterisation procedures or short-term indwelling catheter. 6 of our patients who had positive cultures encountered this complication which modifies the possible outcome of the urine cultures. These patients had pre-instrumenation negative uro-culture and we decided to label them as negative even though at follow-up they all had positive cultures.

Postoperative complications represent a problem for every medical system; their presence leads to an increased cost for medical services and an increase in dissatisfaction among patients and physicians. UTIs are the most frequent hospital-acquired infections [10-26], and they usually appear postoperatively, leading to a longer hospital stay and higher costs for the medical services [14].

Urology departments are the most predisposed to infections, as shown by Jiménez-Alcaide and his collaborators, with the most important risk factor being the indwelled urinary catheters [14].

Antibiotic prophylaxis guidelines are not unanimous and each urologist's adhesion to them is not regulated, nor supervised. As was demonstrated by Khaw and his collaborators in a study conducted with a cohort of 29,530 subjects, the discordance between guidelines and reality was $60 \%$, and in $40 \%$ of the cases, the recommended antibiotic treatment duration was exceeded by 3 days [15].

Also, there is no consensus regarding the use of antibiotics; Lawson et al. noticed in a review of 488 patients who underwent TURP that a total of 30 antibiotic regimens were utilised. The most 
common single antibiotic regimens prescribed were ciprofloxacin (32\%), cefazolin (25\%), and gentamicin $(3 \%)$ [5].

A rise in the risk of asymptomatic bacteriuria was seen in two patients who underwent endoscopic reintervention for haemostasis: one patient had a positive urine culture with a multidrug sensitive Klebsiella spp. 7 days after discharge, without any symptoms. The other only had irritative lower urinary tract symptoms and cloudy urine for which empirical antibiotic treatment was administered, with the subsequent amelioration of these symptoms.

The problem of the clinical significance of postoperative bacteriuria in lower urinary tract endoscopic surgery remains unclear, with only a few consistent studies $[10,11]$. Since one of the inclusion criteria was a negative pre-operative urine culture, our study offers no information about patients with preoperative asymptomatic bacteriuria. According to El Basri et al., preoperative bacteriuria is not a risk factor for postoperative symptomatic UTIs [17].

According to Nitzan et al., UTIs are common among patients with type 2 diabetes mellitus and are more severe; they are caused by more high resistant pathogens and are associated with worse outcomes than in patients without diabetes. Despite this fact, there is no indication that diabetic patients should be treated with asymptomatic bacteriuria. Contrary to said data, the present study only surveyed 3 diabetic patients with a postoperative positive urine culture [18].

All guidelines recommend the administration of antibiotic prophylaxis in men who will undergo TUR-P to reduce the risk of UTIs or asymptomatic bacteriuria [5, 19]. Many studies are evaluating the effects of antibiotic prophylaxis on men undergoing TURP. Although these studies suggested that appropriate antibiotics given to patients with a urinary infection before TUR-P will prevent septicaemia in almost all instances, it is still not clear whether prophylactic antibiotics are used to prevent postoperative infectious complications in men with fewer than 100,000 bacteria per $\mathrm{mL}$ urine are effective and/or necessary. In a meta-analysis by Qiang et al., in this category of patients, postoperative bacteriuria ranged from $1.8 \%$ to $56 \%$ in subjects randomised to placebo or no treatment controls. The overall results showed that antibiotic prophylaxis decreased the frequency of postoperative bacteriuria in men receiving antibiotic prophylaxis vs. placebo or no treatment from $26.5 \%$ to $9.2 \%$ [19]. According to the authors, prophylactic antibiotics reduce postoperative bacteriuria, bacteraemia, highgrade fever, and use of additional perioperative antibiotics in patients with sterile preoperative urine who undergo TURP. EAU guidelines regarding urinary tract infections recommend a single dose of antibiotics as prophylaxis, which reduces the rate of UTIs after TUR-P [20]. The Canadian and Japanese guidelines also recommend that antibiotic prophylaxis should be considered in patients who will undergo TUR-P [21].

The most recent review was reported by Mrkobrada et al., which included 28 trials (4,694 patients) and compared the administration of antibiotics vs. placebo. The rate of infectious complications was higher in patients who underwent TUR-P without antibiotic prophylaxis; indeed, bacteriuria, bacteraemia and fever were recorded in $23.4 \%, 4 \%$, and $26.9 \%$ of the sample, respectively. Administration of antibiotics significantly reduced the rate of bacteriuria $(\mathrm{RR}=$ $0.34 ; 95 \%, \mathrm{CI}=0.30$ to 0.40$)$; bacteraemia ( $\mathrm{RR}=$ $0.84,95 \% \mathrm{CI}=0.71$ to 0.99$)$ and fever $(\mathrm{RR}=0.25$; $95 \%, \mathrm{CI}=0.11$ to 0.56$)$. There was no adverse effect associated with prophylactic administration of antibiotics in these studies [22].

A meta-analysis, realised by Berry et al., analysed the efficiency of antibiotic prophylaxis in men who underwent TUR-P. They identified 32 randomised clinical trials with 4,260 patients, which examined postoperative bacteriuria, concluding that using anti-biotic prophylaxis in patients with low risk who are to undergo TUR-P significantly reduced bacteriuria and the incidence of sepsis. The incidence of bacteriuria was reduced from $26 \%$ to $9.1 \%$, and the incidence of sepsis was reduced from $4.4 \%$ to $0.7 \%$. The most effective classes of antibiotics included: quinolones, cephalosporins, co-trimoxazole, and aminoglycosides. Data from this meta-analysis did not reveal any difference regarding the duration of the treatment. However, the analysis of the studies which used cephalosporins for antibiotic prophylaxis showed a significant difference between the short-term treatment and using a single dose of antibiotic (reducing relative risk to $72 \% \mathrm{vs}$. $52 \%$ ) [23].

In our study, the group of patients who underwent TUR-P was significantly smaller compared to the group which underwent TUR-BT. The incidence of symptomatic bacteriuria was $13.8 \%$, being absent in Group A, and a significantly higher percentage in the group of patients undergoing antibiotic therapy at home (Group C - 28\%). The present study showed that maintaining the urinary catheter for a prolonged period represented a risk factor for the appearance of UTIs - something which was also shown in Schneidewind's study, which concluded that keeping the urinary catheter in place for longer than 3 days increased the risk of symptomatic postoperative bacteriuria [24].

Transurethral resection of the bladder tumour (TUR-BT) is one of the most frequent urologic procedures, which makes it important enough, from the epidemiologic and economic standpoint, to administer preoperative antibiotic prophylaxis. 
However, there are a few studies regarding the efficiency of antibiotic prophylaxis on postoperative infectious complications after TUR-BT, with controversial results. Some studies recommended the usage of preoperative antibiotic prophylaxis for TUR-BT because of the high incidence of postoperative UTIs, which is between $10 \%$ and $40 \%$ [25]. Other studies reported that antibiotic prophylaxis for TUR-BT is not necessary [26, 27].

The American Urology Association (AUA) and the Japanese guidelines recommend the administration of fluoroquinolones, trimethoprim-sulfamethoxazole, penicillins, first- and second-generation cephalosporins, and aminoglycosides before TUR-BT as antibiotic prophylaxis [28]. The European Association of Urology (EAU) states that antibiotic prophylaxis is only necessary if patients have large bladder tumours, with a long resection time, or necrotic tumours [29].

In a retrospective study on 512 patients who underwent TUR-BT, in the group with no antibiotic prophylaxis, the rate of symptomatic UTIs was $13.8 \%$ and that of bacteraemia was $3.1 \%$, in comparison to the other group which received antibiotic prophylaxis, in which the rate of symptomatic UTIs was $22.1 \%$, and that of bacteraemia was $0.57 \%$, thus showing that the incidence of postoperative UTIs was higher in patients who were given preoperative antibiotic prophylaxis [30]. Matsumoto concluded that the incidence of symptomatic UTIs after TUR-BT was lower in patients without antibiotic prophylaxis [31]. We were not able to verify this in the present study because in our clinic there is a standardised protocol for the administration of a single dose of cephalosporin as antibiotic prophylaxis to all patients who are to undergo TURBT and who have a negative urine culture.

The most representative work regarding this is $\mathrm{Di}$ Cosmo's study on 223 patients who did not receive antibiotic prophylaxis; it was concluded that, in the case of 199 of these patients, the prophylaxis would have been unnecessary [32]. However, the present study showed that, in the group of patients who received antibiotic therapy at home after TUR-BT, there were no patients with a positive urine culture, which might indicate the need for a longer period of antibiotic therapy.

Regarding prolonged antibiotic therapy after TURBT, there is no published evidence showing its usefulness. Until Navarette's, there were only two clinical studies, both with small groups of patients. These studies (DeLavierre and MacDermott) reported no significant decrease in the incidence of postoperative bacteriuria in patients who received antibiotic prophylaxis before undergoing TUR-BT (24.1\% in the placebo group vs. $9.4 \%$ in the group which received antibiotic prophylaxis; $17 \%$ in the placebo group vs. $4.5 \%$ in the group which received antibiotic prophylaxis). DeLavierre reported that in both groups there was no symptomatic UTIs. On the other hand, neither of the studies investigated the presence of the risk factors associated with postoperative UTIs, such as the dimensions of the bladder tumour, the presence of a urinary catheter before the surgery $[26,33]$.

In 2018, Navarette published a study in which he investigated 216 patients who underwent TUR-BT and followed 3 different antibiotic prophylaxis protocols, similar to the groups in the present study, with the difference being that in the third group antibiotic therapy was continued at home for 5 days after discharge. The study concluded that the patients who received single-dose antibiotic prophylaxis before TUR-BT had a higher risk of rehospitalization for fever in comparison to those who received prolonged antibiotic therapy - a fact that was also confirmed by the present study [34]. Moreover, according to the above study, tumour necrosis, the number of tumours and a longer hospital stay might predispose the patients to develop infectious complications - a finding that was not proved by the present study. On the other hand, as suggested by the present study, but not confirmed by Navarette's study, keeping the urinary catheter in place for a prolonged period might be an indicator of the necessity of prolonged antibiotic therapy, and the deep resection of the tumour - a parameter which was not taken into account in Navarette's study - may decrease the risk of infectious postoperative complications.

Patients in which urine culture was positive with Klebsiella spp. and Pseudomonas were treated mainly with carbapenems, while those with E. coli and Proteus with fluoroquinolones and third-generation cephalosporins for 7 days. In patients in which Enterococcus was isolated, ampicillin/sulbactam 750 mg twice daily for one week was the treatment of choice. The bacteria identified in our study maintains a pattern observed in other national studies confirming the frequency of the most encountered germs in our population. For example, a study realized in another important centre demonstrated that the most frequent is E. coli $(45.35 \%)$, followed by Klebsiella spp, Enterococcus spp., Enterobacter spp. $(8.18 \%)$ [35].

According to Saba et al. [36], the MAR index helps analyse health risk, as well as to check the extent of antibiotic resistance. In our patients, the values for all the strains were higher than 0.2 suggesting their origin from a high-risk source of contamination where antibiotics are often used.

According to Olayinka et al. [37], Klebsiella and Pseudomonas are major pathogens in healthcareassociated infections, especially in developing countries. The main problem does not arise only from the significant morbidity associated with infections but also because of their high rates of 
FARMACIA, 2020, Vol. 68, 6

resistance is making it more difficult to be treated with cheaper first-line antibiotics [38]. Although we had a relatively low number of positive urine cultures and despite intensive efforts, nosocomial acquisition of multi-drug resistant germs still is a problem of our daily practice.

The present study has some limitations: lack of randomisation, because each patient received

antibiotic therapy which was chosen by his/her attending physician, the small number of patients who underwent TUR-P, the lack of data regarding the usage of antibiotics by the patients before surgery (in the months preceding the surgery), the lack of a local database on antibiotic resistance for the bacteria in the geographic area, and the lack of a database on the incidence of nosocomial infections.

Table IV

Germs identified in positive urine cultures

\begin{tabular}{|l|c|c|c|c|c|c|}
\hline & \multicolumn{2}{|c|}{ Group A } & \multicolumn{2}{c|}{ Group B } & \multicolumn{2}{c|}{ Group C } \\
\cline { 2 - 7 } & TUR-BT & TUR-P & TUR-BT & TUR-P & TUR-BT & TUR-P \\
\hline E. coli & 1 & 0 & 3 & 0 & 0 & 6 \\
\hline Klebsiella spp & 5 & 0 & 12 & 0 & 0 & 5 \\
\hline Enterococus faecalis & 1 & 1 & 6 & 0 & 1 & 2 \\
\hline Pseudomonas aeruginosa & 1 & 0 & 5 & 2 & 0 & 1 \\
\hline Proteus & 1 & 0 & 3 & 2 & 0 & 0 \\
\hline Mixed Flora & 2 & 0 & 0 & 0 & 0 & 1 \\
\hline
\end{tabular}

Table V

Antibiotics used for prophylaxis on patients distributed in groups

\begin{tabular}{|l|c|c|c|c|c|c|}
\hline \multirow{2}{*}{ Given antibiotic/ Number of patients } & \multicolumn{2}{|c|}{ Group A } & \multicolumn{2}{c|}{ Group B } & \multicolumn{2}{c|}{ Group C } \\
\cline { 2 - 7 } & TUR-BT & TUR-P & TUR-BT & TUR-P & TUR-BT & TUR-P \\
\hline Ceftriaxone & 39 & 2 & 106 & 29 & 47 & 31 \\
\hline Cefuroxime & 19 & 2 & 101 & 40 & 27 & 7 \\
\hline Levofloxacin & 6 & - & 6 & 4 & 4 & 1 \\
\hline Ciprofloxacin & 1 & - & 13 & 7 & 8 & 3 \\
\hline Other antibiotics & 6 & - & 8 & - & 4 & - \\
\hline Ceftazidime & 39 & 8 & 73 & 18 & 34 & 12 \\
\hline
\end{tabular}

Table VI

Bacterial Resistance and MAR index

\begin{tabular}{|l|c|c|c|c|}
\hline \multirow{2}{*}{ Identified germ } & \multirow{2}{*}{$\begin{array}{c}\text { Patients (n) } \\
\text { Total 61 }\end{array}$} & Resistant (a) & Tested (b) & Mean MAR index \\
\cline { 3 - 4 } & $\mathbf{a} / \mathbf{b})$
\end{tabular}

According to tables IV-VI our study confirms the known pathogens with Klebsiella, Escherichia coli and Enterococcus being the most frequent findings in follow-up positive cultures. However Pseudomonas aeruginosa and Proteus mirabilis showed greater incidence than other data from different studies high-lighting the prevalence of difficult to treat micro-organism in Romanian society. Table V shows the shift in treatment patterns regarding the use of quinolones which are less used due to recent years update in adverse effects and recommendations to be more precautious in administrating them as first line treatment.

Cehphalosporins are the second in line preferred antibiotics in accordance to European Urology Association guidelines and recommendations. Table VI is presenting MAR index for the analysed pathogens and our study confirms the aggressiveness of existent bacteria at follow-up uroculture in patients who have received anti-biotical therapy. The cut off value for MAR index is under 0.2 and only mixed flora representing $4.94 \%$ showed a normal value of 0.18 . E. coli showed the second best value close to cut-off value, while Klebsiella and Enterococcus had values over 0.5 showing high resistance index. Pseudomonas aeruginosa demonstrated the highest resistance.

\section{Conclusions}

The results of our study showed that prolonging anti-biotic prophylaxis at home is not useful in the case of patients who underwent TUR-P with preoperative sterile urine, but it might decrease the risk of UTI in patients who underwent TUR-BT. In both TUR-P and TUR-BT, keeping the urinary catheter in place for a prolonged period might increase the 
risk of infectious complications. At the moment of enrolling it is still unclear which is the profile of the patient who might benefit from prolonged antibiotic therapy after the discharge from the hospital, because apart from the presence of the urinary catheter, no other factor was proven to increase the risk of postoperative UTIs.

\section{Conflict of interest}

The authors declare no conflict of interest.

\section{References}

1. Reuter MA, Reuter HJ, The development of the cystoscope. J Urol., 1998; 159: 638-640.

2. Goldwasser B, Bogokowsky B, Nativ O, Sidi AA, Jonas $\mathrm{P}$, Many $\mathrm{M}$, Urinary infections following transurethral resection of bladder tumors: Rate and source. J Urol., 1983; 129: 1123-1124.

3. AUA Guideline on Urologic Surgery Antimicrobial Prophylaxis; Published 2008; Reviewed and Validity Confirmed 2011; Amended 2012, available at: www.auanet.org.

4. Clark A, Remarks on "catheter" fever. The Lancet, 1883; 2: 1075-1077.

5. Lawson KA, Rudzinski JK, Vicas I, Carlson KV, Assessment of antibiotic prophylaxis prescribing patterns for TURP: a need for Canadian guidelines?. Can Urol Assoc J., 2013; 7: E530-536.

6. Pestalozzi DM, Böss HP, Knonagel H, Infection's complications after transurethral resection. Helv Chir Acta, 1992; 59: 497-500.

7. Appell RA, Flynn JT, Paris AM, Occult bacterial colonization of bladder tumors. J Urol., 1980; 124: 345-346.

8. Boboia A, Research on applying risk management in the field of quality in order to improve the pharmacy activity. Applying quality management methods to highlight the causes that can lead to risks of errors in activities performed by the pharmacist in pharmacy. Farmacia, 2019; 67(6): 1106-1115.

9. Krumperman PH, Multiple antibiotic resistance indexing of Escherichia coli to identify high-risk sources of fecal contamination of foods. Applied Environ. Microbiol., 1983; 46: 165-170.

10. Vivien A, Lazard $\mathrm{T}$, Rauss A, Infection after transurethral resection of the prostate: variation among centers and correlation with a long-lasting surgical procedure. Eur Urol., 1998; 33: 365-369.

11. Colau A, Lucet JC, Rufat P, Incidence and risk factors of bacteriuria after transurethral resection of the prostate. Eur Urol., 2001; 39: 272-276.

12. National Nosocomial Infections Surveillance (NNIS) report, data summary from October; 1986-April 1996, issued May 1996. A report from the National Nosocomial Infections Surveillance (NNIS) System. Am J Infect Control., 1996; 24: 380-388.

13. Vallejo-Torres L, Pujol M, Shaw E, Wiegand I, Vigo JM, Stoddart M, Grier S, Gibbs J, Vank C, Cuperus N, van den Heuvel L, Eliakim-Raz N, Carratala J, Vuong C, MacGowan A, Babich T, Leibovici L, Addy I, Morris S; RESCUING Study Group and Study Sites, Cost of hospitalised patients due to complicated urinary tract infections: a retrospective observational study in countries with high prevalence of multidrug-resistant Gram-negative bacteria: the COMBACTE-MAGNET, RESCUING study. BMJ Open, 2018; 8(4): 1-9.

14. Jiménez-Alcaide E, Medina-Polo J, García-González L, Healthcare-associated urinary tract infections in patients with a urinary catheter: Risk factors, microbiological characteristics and patterns of antibiotic resistance. Arch Esp Urol., 2015; 68(6): 541-550.

15. Khaw C, Oberle AD, Lund BC, Egge J, Heintz BH, Erickson BA, Livorsi DJ, Assessment of Guideline Discordance With Antimicrobial Prophylaxis Best Practices for Common Urologic Procedures. JAMA Netw Open, 2018; 1(8): 1-11.

16. www.fda.gov.

17. El Basri A, Petrolekas A, Cariou G, Doublet JD, Hoznek A, Bruyere F, Clinical significance of routine urinary bacterial culture after transurethral surgery: results of a prospective multicenter study. $J$ Urology., 2012; 79(3): 564-569.

18. Nitzan O, Elias M, Chazan B, Saliba W, Urinary tract infections in patients with type 2 diabetes mellitus: review of prevalence, diagnosis, and management. Diabetes Metab Syndr Obes., 2015; 8: 129-136.

19. Qiang W, Jianchen W, MacDonald R, Monga M, Wilt TJ, Antibiotic prophylaxis for transurethral prostatic resection in men with preoperative urine containing less than 100,000 bacteria per mL: a systematic review. J Urol., 2005; 173: 1175-1181.

20. Oelke M, Bachmann A, Descazeaud A, Emberton M, Gravas S, Michel MC, European Association of Urology guidelines on the treatment and follow-up of non-neurogenic male lower urinary tract symptoms including benign prostatic obstruction. Eur Urol., 2013; 64: 118-140.

21. Chung D, Lee JY, Recommendations for Antibacterial Prophylaxis in Endourological Procedures. Urogenit Tract Infect., 2019; 14(1): 1-8.

22. Mrkobrada M, Ying I, Mokrycke S, Dresser G, Elsayed S, Bathini V, CUA guidelines on antibiotic prophylaxis for urologicprocedures. Can Urol Assoc J., 2015; 9: 13-22.

23. Berry A, Barratt A, Prophylactic antibiotic use in transurethral prostatic resection: a meta-analysis. $J$ Urol., 2002; 167: 571-577.

24. Schneidewind L, Kranz J, Schlager D, Barski D, Mühlsteadt S, Grabbert M, Queissert F, Frank T, Pelzer AE, Mulitcenter study on antibiotic prophylaxis, infectious complications and risk assessment in TURP. Cent European J Urol., 2017; 70(1): 112-117.

25. Janknegt RA, Prophylaxis in urological surgery. Infection, 1992; 20 (Suppl 3): S213-6; discussion S217-20, S224.

26. Delavierre D, Huiban B, Fournier G, Le Gall G, Tande D, Mangin P, The value of antibiotic prophylaxis in transurethral resection of bladder tumors. Prog Urol., 1993; 3: 577-582 (available in French).

27. Badenoch DF, Murdoch DA, Tiptaft RC, Microbiological study of bladder tumors, their histology and infective complications. Urology, 1990; 35: 5-8.

28. Petca RC, Popescu RI, Mareș C, Petca A, Mehedinţu C, Sandu I, Măru N, Antibiotic resistance profile of 
common uropathogens implicated in urinary tract infections in Romania. Farmacia, 2019; 67(6): $994-$ 1004.

29. Naber KG, Bergman B, Bishop MC, BjerklundJohansen TE, Botto H, Lobel B, Jinenez Cruz F, Selvaggi FP; Urinary Tract Infection (UTI) Working Group of the Health Care Office (HCO) of the European Association of Urology (EAU). EAU guidelines for the management of urinary and male genital tract infections. Urinary Tract Infection (UTI) Working Group of the Health Care Office (HCO) of the European Association of Urology (EAU). Eur Urol., 2001; 40(5): 576-588.

30. Junuzovic D, Hasanbegovic M, Kovacevic-Prstojevic J, The Incidence of Acquired Urinary Tract Infections in Patients After Transurethral Resection of Bladder Tumors. MSM, 2011; 23(2): 91-92

31. Matsumoto T, Kiyota H, Matsukawa M, Yasuda M, Arakawa S, Monden K; Japanese Society of UTI Cooperative Study Group (Chairman; Tetsuro Matsumoto). Japanese guidelines for prevention of perioperative infections in urological field. Int $J$ Urol., 2007; 14(10): 890-909.

32. Di Cosmo G, Verzotti E, Rizzo M, Umari P, Liguori G, Cai T, Trombetta C, Utility of antibiotic prophylaxis before transurethral resection of bladder tumor. Eur Urol Suppl., 2018; 17(2): e333.

33. MacDermott JP, Ewing RE, Somerville JF, Gray BK, Cephradine prophylaxis in transurethral procedures for carcinoma of the bladder. Br J Urol., 1988; 62: 136-139.

34. Panach-Navarrete J, Valls-González L, Sánchez-Cano E, Comparison of three different antibiotic protocols in transurethral resection of bladder tumour and the possible infectious risk factors: A non-randomized, prospective study. Can Urol Assoc J., 2018; 12(11): E466-E674.

35. Golli AD, Nitu Fm, Balsoiu M, Rascu S, Lungu MA, Dinescu SN, Ciobanu-Mitrache L, Glodeanu A, Vacaru M, Olteanu M, Microbiological profile and antibiotic resistance pattern of bacterial uropathogens among hospitalized patients. Farmacia, 2019; 67(1): 167-173.

36. Saba R, Muhammad F, Shahida H, Antibiotic susceptibility pattern and multiple antibiotic resistances (MAR) calculation of extended spectrum $\beta$ - lactamase (ESBL) producing Escherichia coli and Klebsiella species in Pakistan. Afr $J$ Biotechnol., 2011; 10(33): 6325-6331.

37. Olayinka AT, Onile BA Olayinka BO, Antibiotic susceptibility and plasmid pattern of Pseudomonas aeruginosa from the surgical unit of a university teaching hospital in north central Nigeria. Int J Med and Med Sci., 2009; 1(3): 79-83.

38. Linhares, I, Raposo T, Rodrigues A, Frequency and antimicrobial resistance patterns of bacteria implicated in community urinary tract infections: a ten-year surveillance study (2000-2009). BMC Infect Dis., 2013; 13: 1-10. 